\title{
Federal Constitutionalism and Aboriginal Difference
}

\author{
Jean Leclair*
}

The author outlines a new legal approach, which he labels federal constitutionalism, to the question of aboriginal difference in Canada. This approach has the potential to open up more fruitful avenues for the resolution of aboriginal law issues than either the "frozen rights" approach currently adopted by the Supreme Court of Canada or the treaty federalism approach, which posits that treaties should be used to resolve all differences between aboriginals and non-aboriginals. The author outlines the difficulties inherent in both the frozen rights and treaty federalism approaches. Federal constitutionalism, in contrast, drawes its vitality from an organic understanding of Canada's constitutional experience. It would allow aboriginal peoples to be seen as federal actors who have historically shaped the Canadian federation.

Federal constitutionalism is a multi-faceted approach that would permit aboriginal questions to be addressed using the federal principle, thereby allowing the legal focus to move away from section 35 of the Constitution Act, 1982. Aboriginal peoples would be able to exercise the rights of sovereignty over their own internal affairs, while individual aboriginals could participate directly in federal and provincial governments without having to proceed through the intermediary of aboriginal representatives. Federal constitutionalism would allow aboriginal peoples a guaranteed sphere of autonomy, while permitting recognition of their historical interdependence with non-aboriginal peoples.

What follows is a very brief and limited outline of a much broader project - one that seeks to identify the proper legal lens through which "aboriginal difference" can be apprehended in the Canadian context. Given the brevity of this paper, what follows might seem somewhat abbreviated at times and lacking in the nuances that a lengthier essay would permit. ${ }^{1}$

In our contemporary world, law operates as a mechanism of social recognition in that it marks off some practices as being socially

\footnotetext{
* Professeur titulaire, Faculté de droit, Université de Montréal. I gratefully acknowledge the editorial help of Marianne Breese. I also wish to thank François Chevrette for his valuable comments.

1. This paper is drawn from a much longer manuscript that will be submitted for later publication. My argument in this paper is sketchy in places and leaves many fundamental questions unanswered. My objective here is to bring my theory out of the closet.
} 
legitimate and worthy of the investment of collective resources. ${ }^{2} \mathrm{~A}$ juridical concept chosen to translate a particular social reality has enormous consequences because it will imprison that reality within its broad-or narrow - conceptual confines. It will therefore predetermine, to a certain extent, the manner in which the particular social reality can be legally and politically understood.

Since 1982, many people, from Supreme Court justices to legal scholars, be they aboriginal or non-aboriginal, have battled one another over the meaning that should be ascribed to the words "aboriginal rights" found in section 35 of the Constitution Act, 1982. This provision established, for the first time in Canadian legal history, that " $[\mathrm{t}] \mathrm{he}$ existing aboriginal and treaty rights of the aboriginal peoples of Canada are hereby recognized and affirmed."

To encapsulate the last 24 years of interpretation of section 35, one could say that the constitutionalization of aboriginal rights has led to an unfortunate and unsatisfactory reification of aboriginal identity by all concerned, natives and non-natives alike.

On the one hand, the Supreme Court of Canada's understanding of "aboriginal rights" not only fails to acknowledge the political autonomy exercised by aboriginal nations before, and even after, the advent of the Canadian state; it also confines those rights to the culturally significant practices that existed during the pre-contact period. In justification of this approach, the Court explained in $R$. v. Van $\operatorname{der}$ Peet $^{3}$ that the protection afforded to aboriginal rights by section 35(1) stems from the fact that distinctive aboriginal societies lived on the land prior to the arrival of Europeans. The pre-contact period has become the reference period that courts must consider when identifying aboriginal rights. Therefore, according to the Supreme Court, it is antiquity and not native political autonomy that forms the basis of aboriginal rights in Canada. Arguably, decisions such as Delgamunkw ${ }^{4}$ and Haida Nation, ${ }^{5}$ although

2. Pierre Noreau, "L'innovation sociale et le droit - Est-ce bien compatible?" in Le développement social au rythme de l'innovation (Sainte-Foy, Qc.: Presses de l'Université du Québec, 2004) 73.

3. [1996] 2 S.C.R. 507.

4. Delgamunkw v. British Columbia, [1997] 3 S.C.R. 1010 [Delgamunkw].

5. Haida Nation v. British Columbia (Minister of Forests), [2004] 3 S.C.R. 511. 
undoubtedly more generous, have not radically altered this piecemeal approach to aboriginal rights. ${ }^{6}$

The Court's approach to aboriginal rights, based as it is on "cultural distinctiveness" rather than on a recognition of the survival of aboriginal political autonomy, has been the subject of severe criticism, especially from anthropologists. I will not address this criticism except to observe that there is some truth in the anthropologists' crude saying that "people [courts in this case] like their savages naked." ${ }^{8}$ However, in spite of all its shortcomings, the approach adopted by the Supreme Court has allowed some aboriginal communities to make very substantial gains.

On the other hand, some scholars would like us to believe that postsecondary education, health care, social benefits in whatever shape or form, tax exemptions, and so on, can all in some mysterious way be tied to "pre-contact aboriginal socio-political structures." If truth be told, from that perspective, aboriginal rights become the philosopher's stone, the crucible of all imaginable hopes. For obvious strategic reasons, some

6. R. v. Marshall; R. v. Bernard, [2005] 2 S.C.R. 220 is certainly proof of that.

7. Michael Asch, "The Judicial Conceptualization of Culture after Delgamuukw and Van der Peet” (2000) 5 Rev. Const. Stud. 119.

8. Glen Stohr, "The Repercussions of Orality in Federal Indian Law" (1999) 31 Ariz. St. L.J. 679 at 701.

9. Andrée Lajoie et al., "Conception malécite des droits ancestraux", manuscript to be published in Mélanges en l'honneur d'Étienne Le Roy [forthcoming] [my translation and emphasis]:

A small number of our respondents spontaneously mention certain social rights when they are asked what they include in aboriginal rights. They are rights to education, to health, but also certain privileges, including tax exemptions and the freedom to circulate to and from the United States, regardless of borders. To be sure, those rights, except the last one mentioned, may seem not to be reserved to aboriginals, and rather to be part of the socio-economic rights generally enjoyed by the citizens of countries where the welfare state (or what is left of it ...) prevails. But for our interlocutors, at least implicitly, the issue here at stake is no less than one of aboriginal rights, to the extent that they originate from the similar rights which are derived from pre-colonial socio-political structures and which would be integrated into Canadian law under the terms of the "treaties," of agreements concluded between their ancestors and British colonials or, more plainly, as reparation for the spoliation of the territories of which the Malecites were victims, and which prevent them from obtaining these essential services by themselves. 
aboriginal groups have argued unsuccessfully that the social and economic aboriginal rights they were claiming had pre-contact referents. ${ }^{10}$

Thus, the most important flaw in the concept of "aboriginal rights" is that it inevitably encourages recourse to essentialist definitions of aboriginal identity. More specifically, the concept tends to characterize aboriginal peoples in either the "folk-like, feather-wearing" way sometimes envisaged by the Supreme Court, or in the "holistic-traditionbased-consensual-unsoiled by western civilization" way sometimes put forth by aboriginals themselves.

The problem with these substantive approaches is that there is no such thing as an "authentic aboriginal culture," nor, conversely, is there such thing as an "inauthentic aboriginal culture." Authenticity is no longer a given or monadic, indivisible and unquestionable concept. For aboriginals as well as non-aboriginals, identity is a contingent concept that cannot be reified once and for all in "constitutional concrete." Differences in identity between aboriginals and non-aboriginals, and fundamental differences at that, certainly do exist. However, they should be approached in a reflexive manner, rather than an axiomatic or dogmatic one.

There is no doubt that Canada's very diverse aboriginal communities are distinct societies. As Richard F. McDonnell writes in a study of the Crees of Northern Quebec:

[T] hey reproduces [sic] themselves as a population that lays claim to a particular history, that imagines for itself a certain future, which sees itself as harbouring particular values, as engaging in distinct activities, and as having a preference for certain institutional arrangements and biases. ${ }^{11}$

However, they remain "partial societies." In McDonnell's words, "societies are partial in the sense that their membership is economically, politically and informationally drawn into the broader life of the State." 12

10. See e.g. Wasauksing First Nation v. Wasausink Lands Inc., [2004] 2 C.N.L.R. 355 (Ont. C.A.); and National Automobile, Aerospace, Transportation and General Workers of Canada Local 444 v. Great Blue Heron Gaming Co., [2005] 1 C.N.L.R. 147 (OLRB).

11. Richard F. McDonnell, Prospects for Accountability Among the Cree of James Bay (Paper prepared for DINAD, November 1992) at 2 [unpublished].

12. Ibid. at 29. 
In other words, aboriginal communities are not simply aggregations of interchangeable abstract civic individuals. Rather, they are defined by an understanding of tradition, one that enables them to make sense of their world. One particular understanding of a tradition might be dominant in a community at any given point in time. However, it should not lead one to claim that such traditions are never contested within aboriginal communities, or that dissenting perspectives are heretical or inauthentic. ${ }^{13}$ Unfortunately, this is one of the undesirable effects of the substantive aboriginal rights doctrine embraced by the Supreme Court.

Another legal concept promoted by aboriginal legal scholars is known as "treaty federalism." ${ }^{14}$ It is based on the idea that all issues between aboriginals and non-aboriginals should be settled through treaties. As such, despite its name, it is premised not on a federal model but on a confederal one: in other words, it is a system characterized by the fragility of the links uniting the parts to the whole. While the nature of a confederation is to unite several states by treaty, a federation is a union of states founded on a constitution. ${ }^{15}$ Treaty federalism is also a solution that emphasizes the pre-1950 historical horizon of aboriginal/non-aboriginal relationships and fails to give any normative importance to contemporary relationships. It essentially ignores the deep interdependence that was born out of both coerced and voluntary proximity. In its extreme version,

13. The following statement, in a background paper prepared for the Ipperwash Inquiry, is an excellent example of the authentic/heretical approach:

[T] he psychological and social effects of colonization have created divisions within indigenous communities between those people who have embraced a colonized identity and accept the legitimacy of Canadian authority and those who remain rooted in an authentic indigenous identity and assert the authority of their nation.

Taiaiake Alfred \& Lana Lowe, "Warrior Societies in Contemporary Indigenous Communities," online: Indigenous Pathways of Action and Freedom $<$ http://www.taiaiake.com/pdfs/WarriorSocietiesinIndigenousCommunities.pdf $>$.

14. The unavoidable starting points for any reflection on treaty federalism are James [Sakej] Youngblood Henderson \& Russel Barsh, The Road: Indian Tribes And Political Liberty (Berkeley: University of California Press, 1980); and James [Sakej] Youngblood Henderson, "Empowering Treaty Federalism" (1994) 58 Sask. L. Rev. at 241.

15. Olivier Beaud, "Fédéralisme et souveraineté, notes pour une théorie constitutionnelle de la fédération" (1998) Rev. D.P. \& S.P. 83 at 92: "[La confédération] relève du droit international public et [la fédération] du droit public interne; l'une voit son régime juridique déterminé par un traité et l'autre par une constitution.” 
treaty federalism prohibits any direct and individual participation by aboriginal community members in the Canadian political and governmental institutions. All contacts with the Canadian state are to be made by the community's representatives.

Furthermore, treaty federalism fails to be truly federal in character because it focuses only on the autonomy guaranteed by federalism, leaving aside any consideration of the federal solidarity required to maintain the viability of the system. The two-row wampum of the Haudenosaunee Confederacy is often invoked to justify this thesis of separateness. ${ }^{16}$ The following statement by Ovide Mercredi and Mary Ellen Turpel provides a good example:

The First Nations view our relationship today as a continuation of the treaty relationship of mutuality where neither side can act unilaterally without consultation. This partnership is symbolized by the grandfather of all treaties, the Iroquois Confederacy ... two-row wampum between your ancestors and those of the Iroquois. The two-row wampum committed us to a relationship of peaceful coexistence where the First Nations and Europeans would travel in parallel paths down the symbolic river in their own vessels. The two-row wampum, which signifies "One River, Two Vessels," committed the newcomers to travel in their vessel and not attempt to interfere with our voyage. The two vessels would travel down the river of life in parallel courses and would never interfere with each other. It was a co-living agreement. The two-row wampum captures the original values that governed our relationship - equality, respect, dignity and a sharing of the river we travel on. This is how the First Nations still understand our relationship with Canadians. ${ }^{17}$

16. Robert A. Williams Jr., "The Algebra of Federal Indian Law: The Hard Trail of Decolonizing and Americanizing the White Man's Indian Jurisprudence" (1986) Wis. L. Rev. 219 at 291:

When the Haudenosaunee first came into contact with the European nations, treaties of peace and friendship were made. Each was symbolized by the Gus-Wen-Tah, or Two-Row Wampum. There is a bed of white wampum which symbolizes the purity of the agreement. There are two rows of purple, and those two rows have the spirit of your ancestors and mine. There are three beads of wampum separating the two rows and they symbolize peace, friendship and respect. These two rows will symbolize two paths or two vessels, traveling down the same river together. One, a birch bark canoe will be for the Indian people, their laws, their customs and their ways. The other, a ship, will be for the white people and their laws, their customs, and their ways. We shall each travel the river together, side by side, but in our own boat. Neither of us will try to steer the other's vessel.

17. Ovide Mercredi \& Mary Ellen Turpel, In the Rapids: Navigating the Future of First Nations (Toronto: Viking/Penguin, 1993) at 35. 
However, aboriginal documents confirm that although aboriginal peoples did wish to preserve a sphere of autonomy, they also appealed to principles of mutuality and interconnectedness. As John Borrows underlines, at Niagara, in 1764, two wampums were offered to the British: the "[t]wo-row wampum" emphasized autonomy, while the "Belt of Peace," which is less well known, symbolized mutuality and interconnectedness. ${ }^{18}$

Let me be clearly understood. I am not against the signing of treaties. Indeed, such treaties will be absolutely essential to settle territorial claims. However, I find fault with "treaty federalism," because it carries an eschatology according to which the signature of treaties is the only honourable solution for aboriginals to choose. ${ }^{19}$ It follows, therefore, that

18. John Borrows, Rediscovering Canada - The Resurgence of Indian Law (Toronto: University of Toronto Press, 2002) at 150. Borrows writes at 149-50:

In weighing the Gus Wen Tah's ["two-row wampum"] potential to encompass aboriginal control of Canadian affairs reference must be had to other belts exchanged in the same period. The Gus Wen Tah cannot be read in isolation from these other instruments, for they clarify the meaning of the two-row wampum. Just as one should not interpret a treaty solely according to its written words, the Gus Wen Tah should not be read solely on the basis of its woven characters. As will be remembered, the Gus Wen Tah was one of two belts exchanged at Niagara in 1764; the other belt emphasized the interdependence of the Indians of the Great Lakes and the nascent settler population. A ship was woven into one end of the belt, with is bow facing towards Quebec; at the other end of the belt is an image of Michilimackinac, a place in the centre of the Great Lakes regarded as the heart of the Chippewa/Anishinabek homelands. Between these two images were woven twentyfour Indians holding one another's hands, with the person furthest to the right holding the cable of the ship, while the one on the extreme left has his foot resting on the land at Quebec. Representatives of the twenty-two First Nations assembled at Niagara in 1764 touched this "Belt of Peace" as a symbol of friendship and as a pledge to become 'united.' This belt portrays the connection between aboriginal and nonaboriginal peoples and the lands they occupied. In fact, in this belt the Indians are holding on to the ship, pulling it towards them so that they can receive and participate in the benefits from the non-Indigenous population. Aboriginal tradition can thus support a notion of citizenship that encourages autonomy and at same time unifies and connects us to one another, and to the lands we rely on.

19. Henderson, supra note 14 at 328-29:

First Nations' treaties affirm the communal vision of aboriginal peoples.... Treaties are the device by which aboriginal peoples have codified parts of their histories to create a new map of experience... The treaty vision was, and is, at the heart of a humane legal order built on unalterable truths of revealed principles of ecological 
all claims to the effect that natives are at the same time part of an aboriginal political community and part of the larger provincial and national communities are anathema. In taking this stance, treaty federalism fails to recognize that many aboriginals would satisfy themselves with less (for example, a broader delegation of power by the federal government).

More importantly, by focusing entirely on treaties and ignoring the potential of our present constitutional structure, treaty federalism fails to recognize that many aboriginal communities will never be in possession of the political leverage necessary to force non-native governments to sit at the negotiation table. The legal dice are currently loaded against aboriginal peoples. Unless we acknowledge them as "constituent peoples," that is, as essential actors within the Canadian federal state ${ }^{20}$ the task of negotiating treaties might prove impossible for many aboriginal communities. In other words, treaty federalism might very well serve the strong while being but a mirage for the weak.

The essentialist trap into which the aboriginal rights doctrine inevitably leads, combined with treaty federalism's denial of aboriginal and non-aboriginal contemporary interdependence, raises several

law... The trust and promises that take the form of a treaty provides coherence and purpose in a new environment. They lift aboriginal peoples above the commonplace with assurances of partnership in greater things. They give significance to even the drudgeries of life because no effort, however menial it may appear, is meaningless within the context of a fulfilling sacred vision. With the repudiation of the sacred vision embedded in the treaties, there is oppression and stagnation.... Among aboriginal peoples, the spirit of the treaties is equal to the Mosaic Code of the Israelites and equal to St. Paul's vision of Christianity. The vision of the renewing of treaties is equal to Mahatma Gandhi's vision of home rule that stirred a subcontinent, began the long climb of a Third World nation to dignity and initiated the decolonization movement in the United Nations. The treaty vision is similar to Dr. Martin Luther King's dream of individual equality that stirred the dream of African-American minorities.

20. Based as it is on a partial fusion of sovereignty between aboriginal nations and the successive French, British and Canadian Crowns, federal constitutionalism is premised on the idea that aboriginal peoples are prominent actors within our constitutional order. This is contrary to the United States, where tribes are said to "have an extraconstitutional status because of their pre-existing, original sovereignty; because they were existing sovereigns, they were not parties to the U.S. Constitution or state constitutions." David E. Wilkins, American Indian Sovereignty and the U.S. Supreme Court - The Masking of Justice (Austin: University of Texas Press, 1997) at 320, n. 10. 
questions. Is there a legal concept whose roots can be traced back to both aboriginal and non-aboriginal normativity, which can embrace the historical and contemporary horizons of aboriginal/non-aboriginal relationships, and can legally acknowledge the moral interdependency that flows from these relationships? Is there a concept that, rather than requiring a substantive definition of aboriginal identity or the signing of a treaty, would provide each aboriginal community with the political autonomy to enable its members to discuss, agree and disagree among themselves about what they truly are? I believe such a concept does exist, and I choose to call it federal constitutionalism.

In the remaining part of this article, I will briefly describe what I mean by federal constitutionalism. I will then summarize some of the advantages of that approach, though I will not have time to explain the practical legal consequences to which it could lead. More specifically, I will leave until later the difficult question of the substantive legal obligations that would flow from embracing the federal constitutionalism perspective.

Building upon studies by Brian Slattery, Jean-François GaudreaultDesBiens and Patrick Macklem, among others, I want to demonstrate how federalism, understood as a legal and constitutional principle, might provide a more fruitful means of addressing the "aboriginal question" than the paths presently followed by the Supreme Court. In addition, the federal solution advocated here might also avoid the onesidedness of the "treaty federalism" approach. I call this approach "federal constitutionalism" to underline that the federal principle to which I refer is nestled in Canada's federal constitution, and is able to be sanctioned by a court of law.

Federal constitutionalism is a theory that is both abstract and "situated." First, it is premised on the idea that some core legal principles must constantly be met if a system wishes to be called federal. Gaudreault-DesBiens states that: 
a federal alliance necessarily implies a minimum level, first, of trust [or loyalty] between the parties [...] second, of equality between them; third, of autonomy, and fourth, of [...] efficiency in the functioning of the alliance, elements that point, on the one hand, to the concept of subsidiarity and, on the other hand, to the concept of federal arbitration. [...] [Another] principl[e], which [...] ranks alongside those of loyalty, equality, autonomy, and federal arbitration, is the principle of federal solidarity, which can undoubtedly be viewed as stemming from the very nature of a federal alliance. ${ }^{21}$

Gaudreault-DesBiens' approach, however, is too abstract to be of any use on its own. As a distributive enterprise, constitutional law in general - and federal constitutionalism in particular - requires an analysis of both the historical and contemporary contexts of the society within which these abstract principles operate. As such, federal constitutionalism also denies that the scope of the federal principle is exhausted by sections 91 to 95 of the Constitution Act, 1867. Rather than being built upon a formal conception of our constitution, federal constitutionalism is based on an "organic" understanding - organic in the sense of a living constitutional experience. In the words of Brian Slattery, our constitution

is the product of slow and continuing growth, as molded in part by local Canadian influences and tradition [ $\ldots$ and] is grounded in ancient practices generated by interaction between aboriginal nations and British and French officials in eastern North America during the seventeenth and eighteenth century. ${ }^{22}$

The federal constitutionalism perspective opens the door to the recognition of aboriginal peoples as federal actors or constituent peoples. An organic understanding of our constitution leads to the conclusion that aboriginal nations were active participants in the creation of the Canadian federal state, whatever the written constitution might say. The members of the alliance that would eventually form the Canadian federation were not always officially and symbolically recognized in our constitutional documents. Some

21. Jean-François Gaudreault-DesBiens, "The Canadian Federal Experiment, or Legalism without Federalism? Toward a Legal Theory of Federalism" in Manuel Calvo-Garcia \& William L.F. Felstiner, Federalismo/Federalism (Madrid: Dyckinson, 2004) 81 at 112, 122.

22. Brian Slattery, "The Organic Constitution: Aboriginal Peoples and the Evolution of Canada" (1996) 34 Osgoode Hall L.J. 101 at 108-09. 
were initially recognized, then temporarily excluded, and reinstated at a later time. For example, although the aboriginal peoples as federal actors were ignored by the Constitution Act, 1867, their importance was heralded in the Royal Proclamation of $1763^{23}$ and in the many treaties they signed with the French, British and Canadian Crowns. Thus, in connecting the principle of autonomy with that of solidarity, treaties played a significant role in the development of the federal idea in Canada. More recently, section 35 of the Constitution Act, 1982 recognized the aboriginal peoples' ongoing contribution to the building of the Canadian state. ${ }^{24}$

The treatment of the people of New France residing in what became the Province of Quebec in 1763 provides another example. The common law rules regulating the introduction of English law in a conquered colony confirmed the right of these "new subjects" to the use of their own law in private matters. The voice of the "nation canadienne" ${ }^{25}$ was later silenced by the Royal Proclamation of 1763, but it found resonance once again under the Constitution Act, 1791. After

23. Royal Proclamation, 1763 (U.K.), R.S.C. 1985, App. II, No. 1.

24. One should also recall that representatives of the national aboriginal organizations participated, along with the federal and provincial governments, in the negotiations leading to the 1992 Charlottetown Accord.

25. Although predominantly francophone and Catholic, this "nation canadienne" qualified as what we would today call a "multicultural society":

"Multicultural" is a modern term that best captures a fundamental feature of early Canada's make-up. That there was a French Catholic ascendancy is undeniable; in the official Bourden vision of colonial development, only a single cultural identity was fully recognized. Protestants were to be present only temporarily, as prisoners awaiting repatriation or as businessmen in transit. Natives, from this same perspective, were in a state of suspension, thier humanity not fully realized since they had not yet been subsumed, absorbed, and digested into the Christian culture of Europe. As for the black and Native slaves of New France, they were theoretically pieces of property rather than members of a civil society. It is important to recognize this dominant view of the period, but we are not required to perpetuate it in our retrospective study of French-regime society. Although those who set the tone, gave the orders, and wrote the documents in the seventeenth and eighteenth centuries refused to recognize the distinctive identities of cultural minorities, the latter did exist. A real and enduring presence in New France, non-Catholic, non-white elements formed an indispensible and influential part of colonial society.

Allan Greer, The People of New France (Toronto: University of Toronto Press, 1997) at 114. The multicultural fabric of Quebec society is therefore not a recent phenomenon. 
another failed attempt at silencing it by the Union Act, 1840, it was officially recognized in the Constitution Act, 1867. In the words of Roderick A. Macdonald, ours is a "reconstitutive federalism." ${ }^{\text {"6 }}$ Professor Slattery puts it this way: "Canada is an independent, multinational federation, with an autonomous Constitution rooted in several centuries of shared and divergent national experiences"; it is the product of "a merging of the sovereignties of its various component nations, with the aboriginal peoples retaining a measure of their original autonomy." ${ }^{27}$ In short, to claim that the text of the Constitution Act, 1867 does not recognize aboriginal peoples as federal actors is not to say that our constitutional order, seen in its entirety, recognizes no such status. Indeed, aboriginal peoples were, and continue to be, active participants in the federal framework of our country.

The organic approach upon which federal constitutionalism is based has important consequences. By recognizing aboriginal peoples as federal actors, it symbolically destroys the image of aboriginal peoples as passive victims of a history in which they had no part, and also destroys the image of Canada as terra nullius. As well, the organic approach requires that we recognize the factual and moral interdependence that slowly grew out of the relationships between aboriginals and non-aboriginals. ${ }^{28}$ In John Whyte's elegant prose, "we are born into past commitments and inherit them." 29 If federal constitutionalism leads to the conclusion that aboriginal peoples are constituent actors in the Canadian constitutional order, it also forces us to admit that Canada is a multinational federation. That is, federalism in Canada is not just a means of dividing powers territorially, but it is also an instrument designed to take into account the wishes of national minorities to control their collective destinies. ${ }^{30}$ Federal constitutionalism demands that aboriginal (and Québecois) nationalism be taken seriously.

26. Roderick A. Macdonald, "Kaleidoscopic Federalism" in Jean-Francois GaudreaultDesBiens \& Fabien Gélinas, eds., States and Moods of Federalism: Governance, Identity and Methodology (Montreal: Éditions Yvon Blais, 2005) at 264.

27. Slattery, supra note 22 at 107 and 109.

28. Brian Slattery, "First Nations and the Constitution: A Question of Trust" (1992) 71 Can. Bar Rev. 261 at 276.

29. John D. Whyte, "Nations, Minorities and Authority" (1991) 40 U.N.B.L.J. 45 at 49.

30. Will Kymlicka, La voie canadienne: Repenser le multiculturalisme, trans. by Antoine Robitaille (Montreal: Éditions du Boréal, 2003) at 222. 
There are some advantages that would result from adopting the federal constitutionalism approach. First, it brings out the fact that what is at issue is not a mere aboriginal right opposed to the federal or provincial state, but a power conflict, "power" being understood as the capacity of a state to impose its will on citizens, and consequently to constrain dissidents. Aboriginal peoples indeed do not claim a form of freedom in opposition to state intervention, as would an individual. What they do claim is a competing, if not an exclusive, political authority over persons whom the Canadian state also wants to subject to its own authority. And it being symbolically important to call a spade a spade, the federal principle, whose vocation it is to manage this type of conflict of authority, to me seems a more appropriate ground than section 35 on which to found the aboriginal/non-aboriginal relationship.

Second, federal constitutionalism dissociates the issue of the sovereignty of aboriginals over their internal affairs from aboriginal rights having to do with territorial or economic issues. Negotiations are absolutely necessary to settle the latter, since aboriginals and nonaboriginals both have claims to the territory and its resources, but an aboriginal community's sovereignty over its internal affairs requires no such negotiations. Under the federal constitutionalism approach, all aboriginal communities are endowed with sovereignty over their internal affairs. As for their distinct and diverse claims to some control over the territory, these claims would continue to be dealt with under section 35 of the Constitution Act, 1982.

Third, by constitutionally guaranteeing aboriginal communities a sphere of political autonomy over their internal matters - matters which, by nature, are culturally sensitive - federal constitutionalism enables them to deliniate their cultural path without constantly having to gaze into a sixteenth century mirror. In other words, it allows aboriginal communities to escape the "cultural distinctiveness" trap. These communities will decide for themselves, in the exercise of their political autonomy, what they want to be, whatever that might be. Under the federal constitutionalism approach, aboriginal collective self-definition is to be carried out in the political rather than the judicial arena. 
Fourth, federal constitutionalism would remove from the grasp of the Sparrow $^{31}$ limitation test all matters relating to an aboriginal community's internal affairs. Since territorial issues concern matters over which both aboriginal and non-aboriginal communities lay claim, a test aimed at balancing their respective interests is not out of place. However, matters internal to an aboriginal community should in no way be subjected to the interests of the non-aboriginal community (unless the aboriginal community consents to it).

Fifth, constitutional federalism is based on the idea that our individual identities are complex and that they comprise more than a single allegiance. This is true of the aboriginal peoples of Canada as well as non-aboriginal Canadians. Furthermore, constitutional federalism, and more precisely the federal solidarity principle, requires that citizens acknowledge this web of interlocking allegiances and act accordingly. For the federal alliance to survive, it is essential that individual members of aboriginal communities participate directly in the political and governmental institutions of the provinces and of Canada.

Sixth, as I said earlier, federal constitutionalism encourages aboriginal participation in the provincial and federal governments. This participation is essential, since laws adopted by Parliament or by a legislature might affect yet unproven aboriginal or treaty rights. Furthermore, in the words of John Borrows,

aboriginal peoples would resist assimilation through such recognition because their values where the land is concerned could be entrenched in Canada's governing ideas and institutions. They could help to reconfigure Canada in an important way. ${ }^{32}$

Finally, this approach underlines the collective character of the integration of the aboriginal peoples into Canada's constitutional order, as opposed to the individual nature of an immigrant's integration.

$$
* * *
$$

31. R. v. Sparrow, [1990] 1 S.C.R. 1075. The test has been modified in cases such as $R$. $v$. Gladstone, [1996] 2 S.C.R. 723; Delgamuukw, supra note 4; and R. v. Marshall [No. 2], [1999] 3 S.C.R. 533.

32. Borrows, supra note 18 at 146. 
In conclusion, I am not claiming that federal constitutionalism is the "best" solution, though I am claiming that it is better than others. It is more just than the Supreme Court's "cultural distinctiveness" approach. It provides a more coherent legal framework, because it is based on the recognition of aboriginal peoples as constituent peoples of the Canadian federal state. As political entities, and not simply "cultural communities," aboriginal peoples are entitled to a constitutionally guaranteed sphere of political autonomy within Canada's constitutional order. As well, because federal constitutionalism gives equal weight to both the historical and contemporary aspects of aboriginal and nonaboriginal relationships, it is a more appropriate solution than treaty federalism, which emphasizes the isolation and separateness of the two communities. Unlike the treaty federalism approach, federal constitutionalism does not deny the normative consequences stemming from the interdependency that has slowly grown out of the relationships between aboriginals and non-aboriginals. 